\title{
Order outside the Law? Rethinking Amnesty as an ADR Mechanism in Nigeria
}

\author{
Isaac Olawale Albert ${ }^{1}$, Yejide Teslimat Olarinde ${ }^{2}$, Olumayowa Oreoluwa Albert ${ }^{1}$ \\ ${ }^{1}$ Institute for Peace and Strategic Studies, University of Ibadan, Ibadan, Nigeria \\ ${ }^{2}$ National Assembly, Abuja, Nigeria \\ Email: ioalbert2004@yahoo.com, Yjay02@gmail.com, albertmayowa@gmail.com
}

How to cite this paper: Albert, I. O., Olarinde, Y. T., \& Albert, O. O. (2019). Order outside the Law? Rethinking Amnesty as an ADR Mechanism in Nigeria. Beijing Law Review, 10, 913-925. https://doi.org/10.4236/blr.2019.104049

Received: June 2, 2019

Accepted: August 30, 2019

Published: September 3, 2019

Copyright (c) 2019 by author(s) and Scientific Research Publishing Inc. This work is licensed under the Creative Commons Attribution International License (CC BY 4.0).

http://creativecommons.org/licenses/by/4.0/

\begin{abstract}
This paper showcases amnesty as an alternative dispute resolution (ADR) mechanism in Nigeria: focusing particularly on the use and misuse of the system. It presents the Niger Delta amnesty programme as a necessity given the way the crisis in the oil-rich region directly affects the Nigerian economy. It was needed for boosting oil production. However, one does not see any evidence of remorse in those that the country claimed to have given amnesty. The system puts money in their pockets but fails to address the reasons for the youth militancy. Hence criminal and political violence persists in the region. More worrisome is the decision of the government to extend the amnesty programme to career criminals outside the Niger Delta region. Once the government is unable to defeat a criminal group in the country, it dangles amnesty to it. This paper problematizes this as clear evidence of state failure in Nigeria.
\end{abstract}

\section{Keywords}

Amnesty, Alternative Dispute Resolution, Nigeria

\section{Introduction}

The Nigerian state was created by the British in 1914 by bringing the diverse empires, kingdoms and people in the pre-colonial society together. It has been consistently difficult since then to weld the people into a nation. The country is bedeviled by ethnic, religious and environmental crises and it has been difficult to give it a foolproof conflict prevention and management system (Ojo, 2014). From 1967 to 1971 the country fought a civil war as a result of which millions of people were killed. The so-called "Nigerian civil war" was between the Igbo-dominated people of the South East and the rest of Nigeria. The causes in- 
cluded the military coup of January 1966, the counter coup of July 1966, and the persecution of the Igbo people living in Northern Nigeria. The Igbo were considered to have carried out the January coup to eliminate the northern Nigerian leadings in charge of the country. The July 1966 was a revenge mission and then the killing of the Igbo migrants living in the North. The Igbo subsequently attempted to secede from the Nigerian state and this led to the war from July 1967 to January 1970 (Heerten \& Moses, 2014). The Igbo had to surrender but to carefully guide them back into the Nigerian state the federal government declared a "no victor, no vanquished" verdict at the end of it all. Though the Nigeria offer to integrate the Igbo people back into the Nigerian state, they are still marginalized in the scheme of things in the country and this explains the prevailing quest by some Igbo elements to create the "Biafran state". This new move is championed by a movement known as the "Indigenous People of Biafa" (IPOB) led by a young man known as Nnamdi Kanu. It had since been declared a terrorist organization by Nigeria.

There are several other violent conflict issues around the country revolving around environmental, ethnic and religious issues. The most topical include the Niger Delta crisis in the oil region of the South-South, the Boko Haram crisis in the North East, herders' crisis most especially in the North Central, and armed banditry most especially in the North West of the country. There are also cases of criminal violence that have continued to give the government deep concerns. These include rising cases of armed robbery and kidnapping for ransoms.

The popular tradition in Nigeria is for the government to take up arms against any violent groups in the country. This is what is witnessed with the management of the Niger Delta, ethnic and religious crises in the country. In a few cases, the government arrested "troublemakers" and jailed them but all of these seemed not to have been effective as the scale of violent extremism in the country increased. Many Nigerians feel that the prevention and management of violent conflicts in Nigeria would improve with the government giving consideration to alternative dispute resolution (ADR) mechanisms.

What do we mean by Alternative Dispute Resolution (ADR)? The term refers to all "alternative" channels for settling disputes other than formal adjudication. The available options, apart from the existing traditional or cultural institutions in Nigeria, include negotiation, conciliation, mediation, med-arb, and arbitration (most especially the non-binding type). They are most used in matters such as trade disputes, divorce action, and personal injury claims. The understanding is that it would relieve civil courts, which in many cases are severely congested with personal injury suits. Unlike the adversarial litigation, ADR provides the opportunity for disputants to find creative and mutually agreeable solutions to their problems other than a strictly legal procedure would have allowed. It is considered to be less expensive, time consuming and adversarial than adjudication (Barrett \& Barrett, 2004).

There are two broad categories of ADR: the rights based (outcome prediction 
type) and the interest based (facilitative type). In the rights based mechanism, the parties are positional in their actions; they focus exclusively on the protection of their rights and often find it difficult to shift grounds. The process becomes more complex when the disputants are backed up by lawyers insisting on rights protection. This is technically known as "hard negotiation". It involves different types of pressure tactics and what one gets from it is a product of the ability to apply and handle pressure. Reaching agreement under this kind of situation could take a very long time as the two sides engage with the situation as a zero-sum game: one party's loss is the other's gain.

In interest based ADR, on the other hand, the focus is not on whether or not a law had been broken. The focus is on restoring broken relationships. Hence, legal rights are atomized; the focus is on tradeoffs and concession making that could lead to a quicker termination of the conflict in a mutually acceptable manner. The conflict handling rhetoric must therefore change from "it is your problem" to "it is our problem". This is called "soft or collaborative negotiation". When the disputants find it difficult to settle their differences and the facilitative assistance of a third party neutral is sought, the process automatically becomes mediation. In this context, mediation could be defined as facilitated negotiation. The solution must still come from the disputants, as the mediator is not a judge or an arbitrator that could pass judgment.

In one of his works, Llewellyn (2002) provided five possibilities of using ADR in a legal system: 1) the Pre-Charge Entry; 2) Post-Charge/Pre-Conviction Entry; 3) Post-Conviction/Pre-Sentencing Entry 4) Post-Sentence Entry; and 5) Prevention Stage (Llewellyn, 2002). Each of them makes it possible for the laws not to be strictly applied in dealing with the matter. In their own work, Ogbuabor, Nwosu, and Ezike called attention to four avenues for applying ADR to Nigerian justice system. These are the levels of crime prevention, prosecutorial discretion, judicial discretion, and correctional discretion (Ogbuabor, Nwosu, \& Ezike, 2014: pp. 37-39). The point made in this respect is that ADR can be applied to a justice system at any level. It all depends who is taking the steps and for what purpose(s).

The wider acceptability of ADR in the Nigerian justice system is clearly illustrated by the existence of court-connected (or annexed) ADR mechanisms around the country. This encourages or mandates the use of ADR processes in dealing with certain category of cases: with the disputants being provided the onerous opportunity to make input into how their differences are sorted out.

Different organizations strategically position themselves for building ADR capacity in different parts of Nigeria. For example, the Institute for Peace and Strategic Studies, University of Ibadan now offers a professional Master's degree in Negotiation, Mediation and Arbitration. The Master and doctorate programmes of IPSS are also being revised to include a specialization in ADR. This is in addition to the existing five areas of specialization in the programme: 1) internal conflict management 2) international conflict management 3) environmental conflict management, 4) human security and 5) border studies. The 
Institute of Chartered Mediators and Conciliators (ICMC) also positions itself strategically as a civil society institution for providing quality training most especially in mediation. ADR is equally taught at Law Faculties and Nigerian Law Schools around the country.

The intention of the original promoters of ADR in the western legal traditions is that it would be applied to civil cases (Hartley, 2002) while issues relating to state and international crimes (most especially crimes against humanity) would be dealt with strictly using the mainstream criminal justice system. But ADR is being increasingly applied to criminal matters by several governments around the world now. The wisdom in doing is increasingly debated by both academic and policy-oriented analysts. Some people consider it inappropriate to apply ADR in criminal justice. The present paper joins the debate by examining how amnesty, an aspect of ADR, increasingly provides the opportunity for high profile criminals in Nigeria to walk away from justice.

\section{What Is Amnesty?}

In legal terms, amnesty simply refers to "exemption from prosecution for criminal action. It signifies forgiveness and the forgetting of past actions" (The Columbia Encyclopedia 2004). As observed by Albert (2019), “it connotes a state of power asymmetry in a conflict: one party won the war situation and the other lost. In this case amnesty is packaged by the victorious side as part of its post conflict peace building strategies". It benefits members of rebel movements, overthrown regimes, military deserters, and other categories of people that have engaged in one form or infractions against the state of the other but now willing to be forgiven for their crimes committed against the state and the people (Damico, 1975: p. 23). It has to do with forgiving and forgetting a past wrongdoing in a manner recognized by the law.

In practice, amnesty has a close relationship with "pardon" or "immunity" (Oshea, 2002: pp. 1-2). Both amnesty and pardon pertain to the powers invested on the supreme authority of a nation to give forgiveness to persons or a group of persons considered to have contravened the laws of the land. The two are slightly different in terms of their absolution. Whereas amnesty targets the erasure or forgetfulness of the offence, a pardon is not more than just freeing the offender for a pity or forgiving of the offence ${ }^{1}$. In amnesty, it is as if the person never committed the offence. Whereas pardon is granted to individuals, amnesty is given to a group of persons and it is often for offences considered political.

Who has the right to grant amnesty and pardon? The answer to this question would probably vary from one country to the other. In Nigeria, the power to grant both is provided in section 175 (1) and (2) of the 1999 Constitution (as amended) whose provision is in tandem with the provisions Section 212 of the same constitution. It provides as follows:

1) The President may-

${ }^{1}$ http://www.differencebetween.net/miscellaneous/culture-miscellaneous/difference-between-amnes tv-and-pardon/ 
a) grant any person concerned with or convicted of any offence created by an Act of the National Assembly a pardon, either free or subject to lawful conditions;

b) grant to any person a respite, either for an indefinite or for a specified period, of the execution of any punishment imposed on that person for such an offence;

c) substitute a less severe form of punishment for any punishment imposed on that person for such an offence; or

d) remit the whole or any part of any punishment imposed on that person for such an offence or of any penalty or forfeiture otherwise due to the State on account of such an offence.

2) The powers of the President under subsection (1) of this section shall be exercised by him after consultation with the Council of State.

State Governors too can grant pardon either conditionally or unconditionally under section 212 (1a-d) of the 1999 Nigerian constitution. This should follow the recommendation of the State Advisory Council on Prerogative of Mercy headed by the state Attorney General and Commissioner for Justice. Those that could benefit from this include condemned prisoners awaiting execution.

\section{Amnesty Initiatives in Nigeria}

President Umar Musa Yar'Adua popularized the use of the term "amnesty" as an alternative dispute resolution (ADR) process in Nigeria on June 25, 2009 when he declared the Niger Delta amnesty programme following the inability of the Nigerian military to tame the Niger Delta militants (Albert, 2019). The Nigerian state resorted to it when it was proving difficult to militarily defeat the Niger Delta militants sabotaging the oil trade in the country. The grouse of the people of the oil-rich region is that their environment is degraded by oil-prospecting activities of the multinational oil companies in the Niger Delta. They also complain of getting too little from the oil-dependent federation account in the country (Okonta \& Douglas, 2004; Abang, 2014; Asuni, 2009; Obi, 2009, 2010; Akpan, 2011). Several militant youth groups proliferate in the region to address these problems through both criminal and revolutionary violence. They attack oil flow stations, sabotage oil pipelines and hold oil workers hostage. All efforts to stamp out the problems through the use of military force proved above until 2009 when the federal government was forced to reduce the intensity of the problem by granting amnesty to the militants in exchange for laying down their arms. The President claimed to have derived his power from the provisions of section 175 of the Nigerian Constitution. The amnesty was to take effect, "upon the surrender and handing over of all equipment, weapons, arms and ammunition and execution of the Renunciation of Militancy Forms. The "unconditional pardon granted" pursuant to the Proclamation was also extended "to all persons presently being prosecuted for offences associated with militant activities".

It is interesting to note that the Niger Delta amnesty programme did not stop both criminal and political violence in the region; it only reduced the scale of the 
problem (Saheed, 2016; Albert, 2019; Aaron, 2010). For example it took 2016 for another set of over 2000 cult members involved in kidnappings, killings, armed robberies to embrace amnesty in Rivers State. The weapons surrendered by the militants included AK 47 rifles, G3, dane guns, dynamite, NATO guns and detonators (Akasike, 2016).

From the Niger Delta, the sub-culture of granting amnesty to those that violently defy the authority of the Nigerian state spread to the other parts of Nigeria. But the beneficiaries are now no longer people involved in political but criminal violence: most especially armed robbers and kidnappers. The worst-case scenarios were recorded in the South eastern part of the country where kidnapping became a very lucrative business following the examples provided by the Niger Delta militants. Innocent citizens were abducted across the region and were released only after paying heavy ransoms. The relatives of the victims readily paid the amounts negotiated with the abductors rather than wait for the police to help them rescue their loved ones.

Overwhelmed by the intensity of this problem in 2011, Governor Theodore Orji of Abia State chose amnesty as a strategy for managing the ugly situations around him. He offered to grant amnesty to as many kidnappers and armed robbers that were willing to lay down their arms. He wondered why the Niger Delta amnesty programme was not extended to Abia state to enable the criminals there benefit from the project. Explaining why he opted to use amnesty for bringing peace back to his state, the Governor observed that "The disadvantages of kidnapping are massive, because it has driven away contractors and investors from the state and Aba in particular, making development difficult". Appealing to the criminals, he said "All the arms you have packed somewhere bring them out for the world to see so that the Federal Government will accept you into the amnesty programme" (Uwugiaren, 2010).

A few other Governors followed suit by asking the criminals in their jurisdictions to drop their arms in exchange for jobs and other amnesty-associated opportunities. This happened in Benue, Ondo, Imo etc. There were so many of such amnesties granted that the state governors appeared to be competing with one another on it. There was a clash in February 2018 when a group of cultists declared wanted by Rivers state government went to the nearby Imo state to get amnesty. Speaking during a bills signing ceremony at the Government House Port Harcourt in February 2018 on the matter, Governor Nyesom Ezenwo Wike of Rivers state said: "Just yesterday, the Governor of Imo State granted amnesty to the cultists we declared wanted. These are cultists of the Don Wanny gang who killed 23 persons on New Year Day ... These are cultists who have been killing security agents. That amnesty offered by Governor Okorocha cannot cover Rivers State. These criminal cultists are still wanted for their crimes against Rivers State and her people". The Governor could not but read political meanings to the amnesty imbroglio. It was to him sabotage by the APC Governor (Okorocha) to compromise the security of Rivers, a PDP state. He said, "Before Governor Rochas Okorocha granted amnesty to those who killed our 
people, he did not deem it fit to call me... They should always weigh the implications of these actions to the security of the region. Whether you are in PDP or APC, there is no need to politicise security" (Vanguard February 6, 2018).

Taking a legal look at the matter, the Rivers State Attorney-General and Commissioner of Justice, Emmanuel Aguma, argued that the Governor of Imo State has no constitutional power to grant amnesty to any person for an offence committed in Rivers State. To back up his argument, he cited provisions of Section 212 of the Constitution of the Federal Republic of Nigeria 1999, as amended. According to him, Okorocha could only grant amnesty with regard to offences created by the House of Assembly of Imo State. By virtue of Section 1fb of the constitution, he argued that even the President of Nigeria could only grant amnesty with regard to offences created by an Act of the National Assembly (Ebiri, 2018). Those granted amnesty in Imo state were advised to maintain a safe distance from Rivers State (Azubuike, 2018).

The House of Representatives in Abuja joined the amnesty debate in Nigeria when it welcomed a bill, known as the Economic Amnesty, sponsored by Linus Okorie (Peoples Democratic Party, Ebonyi) on June 14, 2017. In it, the proposal was made for those engaged in corrupt practices to be granted amnesty if they could surrender a part of the loot. The bill was widely condemned by Nigerians fearing that if passed could lead to many forms of financial crimes such as trafficking in drugs, armed robbery, kidnapping and hostage taking. The bill was challenged for not being in tandem with the spirit of sections 15, 42, and 45 of the 1999 Constitution of Nigeria in addition to being insensitive to whatever UN Conventions that Nigeria must have signed in the past imposing a duty on the country to fight corruption. To a Senior Advocate of Nigeria, Femi Falana, the bill:

"... is discriminatory as it is designed to shield looters of our commonwealth alone from prosecution contrary to the letter and spirit of Section 42 of the Constitution. It is dangerous as it is meant to legitimize official corruption and impunity in the country ... If the bill is signed into law, all criminals who have been convicted and jailed for fraud, stealing, kidnapping and armed robbery are automatically entitled to similar amnesty and pardon" (Akinkuotu et al., 2017: p. 7).

The position of Alhaji Balarabe Musa, a former Governor of Kaduna state and a leading human rights activist in Nigeria, is not different from that of Falana. He was disappointed not only that the bill was proposed but more importantly welcomed by the Nigerian parliament. To him, the bill "is immoral and it shows the level of moral degeneration the country has attained especially at the leadership level ... The proposal, to me, is a way of legitimizing corruption, because you are telling people to loot, then you are set free. This is not good for Nigeria .... and for the fight against corruption".

However, a Senior Advocate of Nigeria, Mallam Yusuf Ali looked at the matter from a different perspective. To him, the bill became necessary given the difficulties faced by Nigeria over the years in recovering stolen assets. He asked "Do we want an eye for an eye or we want stolen money to be recovered? If it is an 
eye for an eye, how many corrupt people have you been able to catch? How many of them have you been able to recover stolen money from? I support any means by which stolen money can be recovered and used for the development of the people" (Akinkuotu et al., 2017: p. 7).

\section{Discussion: Order outside the Law?}

It is now time to revisit the poser in the title of this paper: order outside the law? Is amnesty not an attempt to ensure order outside the law? By this is meant that the use of amnesty by the Nigerian state is probably a form of self help strategy for dealing with issues requiring strict legal procedures. It is an attempt to cut corners in ensuring public order. In other words, the way amnesty is used in $\mathrm{Ni}$ geria smacks something of an illegality in a criminal justice system. It is not.

It is hereby argued that the laws of Nigeria recognize amnesty. As earlier argued, the President of the country and state Governors have the right to use it for managing sensitive conflict situations. But it is theoretically expected to be sparingly used by a government to support the existing legal order in a moment of complex political emergencies. The original intention is that this kind of conflict management style would be used to douse political tension. To this extent, it could be said that the government was right in giving amnesty to Niger Delta militants whose violent activities posed a great threat to Nigeria's foreign earnings from the oil sector. Even then, the Niger Delta amnesty programme is never without some problems. The first is the blanket nature of the deal: it covers all offences that the beneficiaries might have committed and they did not have to state them formally. In the words of the proclamation, anybody that benefitted from the scheme was assumed to have "directly or indirectly participated in the commission of offences associated with militant activities in the Niger Delta". The nature of these offences, which must have included international humanitarian crimes, was not defined. Hence, all those that sought to free themselves from the myriads of crimes committed in the Niger Delta and ven in the neighbouring states at this time simply signed unto the amnesty programme to free themselves from arrest and prosecution.

Many of the "ex-militants" did not see the amnesty programme as having anything to do with the crimes they committed in the past; it was to them an opportunity to get from the government the benefits denied them in the past. They did not see it as a forgiveness of past criminal activities. It is to them their legitimate rights. It was with this frame of mind that one them interviewed by Dr. Owonikoko Babajide Saheed in Yenagoa, Bayelsa State September 13, 2014 said:

When they came to talk to us to submit our arms and accept the amnesty, the federal government promised us several things. They said they would build us houses, buy us cars and would set us up. It is over five years now that I have disarmed and accepted the amnesty. Where are all the promises? The $\$ 65,000$ that government is paying me is not enough for me to take care of my family. I have two wives and 9 children. And government is saying we should not go back to 
the creek (the word 'creek' here symbolises resumption of militancy or criminality). How is that possible? (cited from Saheed, 2016: p. 73).

The above statement is symptomatic of another major problem with the Niger Delta amnesty programme: the tragedy of unmet expectations. According to the above ex-militant, the government promised to build houses for the militants, buy them cars and help to build and grow their businesses. Of course the ex-militant was merely speaking in allegories here but the impression he was trying to create was that the militants were promised more than the government could provide. The focus was not on making the militants regret and formally denounce whatever they did wrongly in the past. This is a paradox in an amnesty programme. In a normal situation, those granted amnesty are those expected to promise the government a new lease of life and not the other way round.

While it is generally taken that the President of Nigeria has the power to grant amnesty, some Nigerian lawyers believe that the Niger Delta one was not well executed. The position of these lawyers is that it is difficult for a group of people who have not been formally convicted of a criminal offence to be granted amnesty (pardon). For example, Lateef Fagbemi (SAN) is of the opinion that the act of granting amnesty to the militants before establishing the criminal nature of their activities would create more problems than solved. He noted "These people have not been convicted. So when you say you forgive somebody whose guilt has not been established to me, there cannot be any worse scenario to insult their innocence... Why not explore legal processes. If they are guilty, they are guilty. You can then talk about trying to forgive them" (Aborisade 2009: p. 8).

Even when taken to have been properly applied, it is difficult to conclude that the Niger Delta amnesty actually led to sustainable order in the region. It merely led to a reduction in the attacks on oil installations and workers. This boosted the oil production capacity in the Niger Delta. But some of those that actually benefitted from the scheme merely used it to free themselves from past heinous crimes committed. Sooner than later some of them returned to criminality. A good case for illustrating this is that of one Sola Paul who was arrested in 2017 for being an accomplice of the suspected billionaire kidnapper, Chukwudumeme Onwuamadike, a.k.a Evans. He claimed to be one of those granted amnesty in 2009 by the federal government in Bayelsa State. He was earning N65,000 monthly from the amnesty programme of the Nigerian government for Niger Delta Militants before meeting Evans. His testimony is instructive. He observed that:

I went into sea diving job for which I was paid sums ranging from $\mathrm{N} 50,000$ to $\mathrm{N} 500,000$ for items recovered. But while working as divers all of us were still in the militant camp at Bayelsa, Calabar and Delta ... At times, we would break pipelines or kidnap oil workers, especially foreigners working with oil companies, and they used to pay ransom fast... It was my master, Mr. George Suboma, who owned the camp and the guns we used for militancy. We got annoyed with the oil companies because they did not care to employ indigenes of the states or 
develop the areas... The amnesty was granted us in 2009, during the late President Yaradua's regime. In 2010, I met Evans ... When President Yaradua died, they started owing us amnesty allowance ... Evans later called me" (Nwachukwu, 2017).

There are several other issues around how Nigeria practices amnesty. First and foremost, amnesty is supposed to be a stopgap in conflict prevention and management: something done to complement the existing legal system in emergency situations. It is never intended in any part of the world to replace or supplant the existing legal order as now witnessed across Nigeria. It should not be a permanent strategy for appeasing criminals that the government cannot tame. President Yar'Adua turned to it in 2009 when it was becoming very difficult to defeat the Niger Delta militants. Governors turn to it when it becomes difficult for them to truly function as the chief security officers of their states.

However, the amnesty declared by state governors raises more questions than answers. The amnesties were granted to kidnappers and armed robbers in the South eastern parts of the country and to bandits and cattle rustlers in some parts of Northern Nigeria. This is straight case of state failure. It is difficult to fathom how armed robbers and kidnappers who kill and maim innocent citizens would be granted amnesty and "compensated" by the government with resources for their rehabilitation. The laws of Nigeria are quite clear on how to treat such criminals. The Criminal Code Act, CAP C38, LFN 2004, also provides a penalty for kidnapping. The law provides in Section 364 that-

"Any person who-

1) Unlawfully imprisons any person, and takes him out of Nigeria without his consent; or

2) Unlawfully imprisons any person within Nigeria in such a manner as to prevent him from applying to a court for his release or from discovering to any other person the place where he is imprisoned, or in such a manner as to prevent any person entitled to have access to him from discovering the place where he is imprisoned,

Is guilty of a felony and is liable to imprisonment for ten years.

In September 2017, the bill sponsored by Senator Isa Misau on death sentence for whoever engages in kidnapping was passed into law after a consideration of the report by Senate committee on Judiciary, Human Rights and Legal Matters. The bill in Clause 1 (3) stated: "Whoever is guilty of the offence and then results in the death of the victim shall be liable on conviction to be sentenced to death." The Clause 3 of the bill provides a 30-year jail term to anyone who colludes with abductor to receive any ransom for the release of any person who has been wrongfully confined.

A number of Nigerian states have also passed the law prescribing death sentence for kidnappers. It makes sense to enforce this kind of law than to be granting amnesty and compensation to individuals engaged in kidnapping. Ditto armed robbery. The laws on this specifies death sentence where the robbery is 
committed with firearms. The federal government even has a special unit of the Nigerian Police dedicated to the management of the problem. It is known as Special Anti Robbery Squad (SARS). It therefore becomes difficult to understand why and how any government would leave any of these laws and institutions to start granting amnesty to robbers, kidnappers, bandits and cattle rustlers. This can only happen in a state that has reached advance stage of failure.

What happens to be rights of the victims where amnesty is granted to armed robbers, kidnappers, bandits and cattle rustlers? This is another question that must be given adequate attention as one assesses the use of amnesty in Nigeria. Can there be sustainable peace where the perpetrators of these heinous crimes that ought to have been punished but granted amnesty and compensation while the victims are not granted any reparation?

\section{Summary and Conclusion}

This paper showcases amnesty as an ADR method but calls attention to the abuse of its use. The Niger Delta amnesty programme which started in 2009 is said to be the most mentioned in Nigeria. It was a necessity given the way the crisis in the oil-rich region directly affects the Nigerian economy. But a blanket amnesty, as witnessed, would not help the region. So far, one does not see any evidence of remorse in those that the country claimed to have given amnesty. Hence, the problems of the region would continue for many more years to come until the government is ready to deal with the problems in the area with sincerity. The solutions to the problems in the region should focus on the root causes of the problems the government seeks to solve by granting amnesty to the Niger Delta militants.

Following this historic intervention, some states in the South eastern parts of the country started to apply the amnesty option to the management of kidnapping and armed robbery in questionable ways. What ties the cases together is the readiness of the Nigerian state to drop its mainstream legal system and the use of military force to prevent and manage conflicts at the altar of using amnesty to placate criminals to stop what they do. In the process, several criminals walked out of justice in different parts of the country. This is difficult to understand. Granting amnesty to career criminals outside the Niger Delta region is clear evidence of state failure in Nigeria. The retribution theory of justice emphasizes the role of punishment to deter subsequent or prospective perpetrators of offenses. But in Nigeria, the reverse seems to be the case with the ongoing practice of amnesty in the country. We are of the opinion that all suspects should be subjected to trial and have clear judiciary pronouncement from a competent law court determining the culpability of the crime on the collective survival of the citizen without interference from any other arm of government. Again, it is at the prerogative of the state, to determine if they will be freed and pardoned but first, the needful and meaningful should be done and be seen to be done. 


\section{Conflicts of Interest}

The authors declare no conflicts of interest regarding the publication of this paper.

\section{References}

Aaron, K. K. (2010). Beyond the Euphoria: Challenges of Amnesty Implementation for Sustainable Peace in the Niger Delta. In K. K. Aaron, \& D. George (Eds.), Placebo as Medicine: The Poverty of Development Intervention and Conflict Resolution Strategies in the Niger Delta Region of Nigeria (pp. 201-245). Port Harcourt: Kemnela Publications.

Abang, S. O. (2014). The Niger Delta Crisis and the Roles of Governmental Agencies in Nigeria. African Identities, 12, 180-195. https://doi.org/10.1080/14725843.2014.885779

Akasike, C. (2016). 2,000 Kidnappers, Armed Robbers Embrace Amnesty in Rivers. Punch, October 23.

https://punchng.com/2000-kidnappers-armed-robbers-embrace-amnesty-rivers

Akinkuotu, E., Adesomoju, A., Ramon, O., \& Aluko, O. (2017). Falana, Balarabe, Cacol, Others Condemn Amnesty Bill for Looters (p. 7). The Punch, July 11.

Akpan, O. (2011). The Niger Delta Question and the Peace Plan. Ibadan: Spectrum Books Ltd.

Albert, I. O. (2019). Hazy Agenda, Multiple Interests: Stakeholders Engagement with the First Phase of the Niger Delta Amnesty Deal in Nigeria. Beijing Law Review, 10, 656-670. https://doi.org/10.4236/blr.2019.104037

Asuni, J. (2009). Understanding the Armed Groups of the Niger Delta (pp. 1-19). Special Report 229, Washington DC: United States Institute of Peace. http://digitalcommons.law.scu.edu/lawreview/vol45/iss4/7

Azubuike, C. (2018). Do Not Come into Rivers State-Wike Warns Beneficiaries of Okorocha's Amnesty. Daily Post, February 6.

http://dailypost.ng/2018/02/06/not-come-rivers-state-wike-warns-beneficiaries-okoroc has-amnesty

Barrett, J. T., \& Barrett, J. P. (2004). A History of Alternative Dispute Resolution: The Story of a Political, Cultural, and Social Movement. San Francisco, CA: John Wiley and Sons, Inc.

Damico, A. J. (1975). Democracy and the Case for Amnesty. Gainesville, FL: Florida Presses.

Ebiri, K. (2018). Okorocha Can't Grant Amnesty for Offences Committed in Rivers, Says $A G$. The Guardian, 8 February.

https://guardian.ng/news/okorocha-cant-grant-amnesty-for-offences-committed-in-riv ers-says-ag

Hartley, R. E. (2002). Alternative Dispute Resolution in Civil Justice Systems. New York: LFB Scholarly Publishing LLC.

Heerten, L., \& Moses, A. D. (2014). The Nigeria-Biafra War: Postcolonial Conflict and the Question of Genocide. Journal of Genocide Research, 16, 169-203.

https://doi.org/10.1080/14623528.2014.936700

Llewellyn, J. (2002). Building, Strengthening and Transforming Communities: Exploring the Possibilities for Restorative Justice in Jamaica. West Indian Law Journal, 27, 77-110.

Nwachukwu, J. O. (2017). Billionaire Kidnapper: I Was a Militant, Earning N65,000 Monthly from Amnesty-Suspect, Sola Paul. Daily Post, June 20. 
http://dailypost.ng/2017/06/20/billionaire-kidnapper-militant-earning-n65000-monthl y-amnesty-suspect-sola-paul

Obi, C. (2009). Nigeria's Niger Delta: Understanding the Complex Drivers of Violent Oil Related Conflicts. African Development, 34, 103-128. https://doi.org/10.4314/ad.v34i2.57373

Obi, C. (2010). Oil Extraction, Dispossession, Resistance, and Conflict in Nigeria's Oil-Rich Niger Delta. Canadian Journal of Development Studies, 30, 219-236. https://doi.org/10.1080/02255189.2010.9669289

Ogbuabor, C. A., Nwosu, E. O., \& Ezike, E. O. (2014). Mainstreaming ADR in Nigeria's Criminal Justice System. European Journal of Social Sciences, 45, 32-43.

Ojo, E. O. (2014). Nigeria, 1914-2014: From Creation to Cremation? Journal of the Historical Society of Nigeria, 23, 67-91.

Okonta, I., \& Douglas, D. (2004). Where Vultures Feast: Shell, Human Rights and Oil. London: Verso Books.

Oshea, A. (2002). Amnesty for Crime in International Law and Practice. The Hague: Kluwer Law International.

Saheed, O. B. (2016). Kidnapping in Pre- and Post-Niger Delta Amnesty. International Journal of Peace and Conflict Studies, 3, 63-77.

Uwugiaren, I. (2010). Nigeria: Kidnapping as Big Business in South-East. Leadership, 27 June. https://allafrica.com/stories/201006281327.html

Vanguard (2018). Don Wanny Killer Colleagues: Imo State's Amnesty Does Not Cover Rivers State-Gov Wike. Vanguard, February 6.

https://www.vanguardngr.com/2018/02/don-wanny-killer-colleagues-imo-states-amne sty-not-cover-rivers-state-gov-wike 